ISSN pr. 2412-608X, ISSN on. 2412-6098

Масличные культуры.

Вып. 4 (184), 2020

\section{Обзорные статьи}

УДК 631.52:633.854.78

DOI: $10.25230 / 2412-608 X-2020-4-184-71-86$

\section{Особенности селекционно- семеноводческой работы и технологических приемов возделывания подсолнечника в связи с изменением климата (обзор)}

\section{А.Д. Бочковой,}

зав. лабораторией, д-р с.-х. наук

В.А. Камардин,

ст. науч. сотр., канд. с.-х. наук

ФГБНУ ФНЦ ВНИИМК

Россия, 350038, г. Краснодар, ул. им. Филатова, д. 17

Тел.: (861) 254-23-33

E-mail: vniimk@vniimk.ru

Для цитирования: Бочковой А.Д., Камардин В.А. Особенности селекционно-семеноводческой работы и технологических приемов возделывания подсолнечника в связи с изменением климата (обзор) // Масличные культуры. - 2020. - Вып. 4 (184). С. $72-87$.

Ключевые слова: подсолнечник, селекция, семеноводство, агротехника.

На основании анализа отечественных и зарубежных источников научной литературы приведены сведения о современном состоянии и перспективах селекционно-семеноводческой работы и технологических приемов возделывания подсолнечника в связи с изменением климата. Установлена важная роль соблюдения научно обоснованных приемов агротехники для получения максимального экономического эффекта при внедрении новейших селекционных достижений. Обсуждаются вопросы дальнейшего совершенствования научно-исследовательских работ, связанных с увеличением производства подсолнечника.

UDC 631.52:633.854.78
The peculiarities of breeding and seed growing work and technological methods of sunflower cultivation in relation to climate change (review).

A.D. Bochkovoy, head of department, doctor of agriculture

V.A. Kamardin, senior researcher, $\mathrm{PhD}$ in agriculture

V.S. Pustovoit All-Russian Research Institute of Oil Crops

17 Filatova street, Krasnodar, 350038, Russia

Tel.: (861) 254-23-33

E-mail: vniimk@vniimk.ru

Key words: sunflower, breeding, seed growing, agricultural technology.

The review provides the information on the current state and prospects of breeding and seed growing work and technological methods of sunflower cultivation in relation to climate change based on the analysis of domestic and foreign sources of scientific literature. We established the important role of observing scientifically based agricultural technologies for obtaining the maximum economic effect when introducing the latest breeding achievements. The article reviews the issues of further improvement of research work related to the increase in sunflower production.

Погодные условия оказывают существенное влияние на урожайность подсолнечника и качество его семян. Так, по данным В.С. Пустовойта, содержание масла в ядре семян подсолнечника на полях ВНИИМК в среднем за 1926-1938 гг. составляло $56,0 \%$ с колебаниями от $49,2 \%$ в 1930 г. до 61,8 \% в 1933 г. [1; 2]. При этом было отмечено, что урожайность зависела не столько от суммы годовых осадков, сколько от распределения их по основным периодам развития подсолнечника. Установлено, что наиболее высокая масличность была отмечена в годы, когда в период цветения растений выпадало пониженное количество осадков.

На основании многолетних экспериментальных данных ВНИИМК было предложено разделить период от цветения до полной спелости на две фазы. Первая фаза продолжается от начала цветения до появления желто-зеленой окраски корзинки, в течение которого происходит формирование семян с одновременным резким увеличением содержания масла в ядре. Вторая фаза 
продолжается от появления желтозеленой окраски до полной спелости (желто-бурая корзинка). В течение этой фазы интенсивно проходит налив семян, повышается масса 1000 семян при неизменном уровне масличности ядра. Первый период был назван фазой формирования семян и установления их масличности, а второй - фазой налива семян и установления их крупности [3]. При анализе условий выращивания без учета особенностей каждой фазы не удавалось объяснить явления формирования крупных семян с низкой масличностью ядра или формирования мелких семян с высокой масличностью.

Неблагоприятные погодные условия (суховеи, чрезмерно высокая температура воздуха) в первой фазе являются причиной пустозерности и низкой масличности семян. Такие же экстремальные условия во второй фазе (налива) резко снижают массу 1000 семян, не внося существенных изменений в их масличность [2].

В районах недостаточного увлажнения главным лимитирующим фактором являются запасы влаги в почве. Именно они были определяющими для реализации потенциала урожайности, высокой масличности и массы 1000 семян. Поскольку запасы влаги в глубоких горизонтах почвы создаются главным образом осенними, зимними и весенними осадками, выпадающими до начала вегетации, то для получения высоких урожаев подсолнечника в районах недостаточного увлажнения решающее значение имеют именно эти осадки.

На основании опытных данных, полученных во ВНИИМК, была разработана градация по оптимальной густоте стояния растений подсолнечника в товарных посевах в зависимости от глубины промачивания почвы на момент посева. В частности, рекомендуется оставлять на 1 га при промачивании на глубину 2,5-3 м 40-50 тыс. растений, 1,5-2 м - 30-40 тыс., а до 1 м - 20-30 тыс. растений [4]. Анало- гичные рекомендации содержатся и в других научных исследованиях [5].

Обширная научная программа по изучению технологии возделывания масличного подсолнечника проводилась во ВНИИМК, начиная с 1912 г. Многолетние опыты позволили разработать комплекс агротехнических приемов для получения высокого и стабильного урожая подсолнечника, сохранения его качества [6].

При разработке прогрессивной технологии первичного и промышленного семеноводства под руководством академика B.C. Пустовойта были использованы принципиально новые подходы к изменению принципов и схемы семеноводства $[7 ; 8 ; 9 ; 10]$. Большое внимание было обращено на изучение агротехнических приемов, гарантирующих получение высококачественного семенного материала подсолнечника $[11 ; 12 ; 13 ; 14 ; 15]$. Оценка влияния экологических условий на качество семенного материала подсолнечника позволила выделить наиболее благоприятные по почвенно-климатическим условиям зоны для получения семян с высокими посевными качествами и урожайными свойствами [16; 17; 18; 19]. Выращивание семенного материала подсолнечника на фоне внесения высоких доз азотно-фосфорных удобрений дало возможность разработать и внедрить способ биологического обогащения семян элементами минерального питания [20; 21].

Проведенные во ВНИИМК многолетние исследования способствовали организации региональных селекционно-агротехнических программ и созданию сортов подсолнечника, наиболее эффективно использующих местные благоприятные условия внешней среды и способных противостоять действию стрессовых факторов, типичных для данной почвенноклиматической зоны [22]. Методика селекции подсолнечника разрабатывалась B.C. Пустовойтом с 1912 г., постоянно совершенствовалась вплоть до конца 1970-х годов. В нее впервые было вклю- 
чено множество новых приемов, направленных на достижение максимальной эффективности работ $[1 ; 23 ; 24 ; 25 ; 26 ; 27$; $28 ; 29]$. В конечном итоге это привело к достижению выдающихся результатов по селекции и семеноводству подсолнечника $[30 ; 31]$. Достаточно упомянуть, что в период 1965-1975 гг. в мире сортами подсолнечника селекции ВНИИМК было занято $80 \%$ от всех посевных площадей под этой культурой [30].

История селекционной работы с подсолнечником представляет динамически развивающийся процесс, мобильно реагирующий на изменения лимитирующих факторов при выращивании этой культуры. Направление селекции может быстро меняться в зависимости от открытия новых источников исходного материала, внедрения новых методов и технологий, ускорения селекционного процесса, резкого изменения патогенной ситуации и агротехнических приемов возделывания. В последние годы к ним добавились проблемы, связанные с глобальным изменением климата. Они выражаются повышением температуры и увеличением концентрации $\mathrm{CO}_{2}$, резкими климатическими аномалиями и меньшей влагообеспеченностью сельского хозяйства. Так, например, за период с 1901 по 2005 гг. средняя температура в Европе увеличилась на $0,9{ }^{\circ} \mathrm{C}$, а по отдельным регионам увеличение температуры выявлено в значительно большей степени [32]. Средняя температура на планете за период 19062005 гг. увеличилась на $0,74{ }^{\circ} \mathrm{C}$ по сравнению с предыдущим столетием, количество осадков в странах Северной Европы увеличилось от 10 до $40 \%$, в то время, как в странах Южной Европы - уменьшилось на 20 \%. В Болгарии за последние 20 лет температура в регионе Добрича увеличилась на $0,8-1,0{ }^{\circ} \mathrm{C}$, а влажность почвы уменьшилась, особенно в период вегетации [33].

По данным Всемирной Метеорологической организации, глобальная средняя температура в 2015 г. превысила средний уровень $1961-1990$ гг. на $0,76{ }^{\circ} \mathrm{C}$, а пятнадцать из шестнадцати самых жарких лет наблюдались в настоящем столетии [34].

Подсолнечник является культурой весеннего срока посева и обычно выращивается в засушливых условиях, вследствие чего может быть более уязвимым к воздействию теплового стресса в фазе цветения и засухи в течение периода вегетации. В последние годы производство подсолнечника переместилось в большинстве стран из регионов с достаточным количеством осадков и плодородными почвами в менее благоприятные почвенно-климатические зоны [35]. Так, например, в Китае произошло перемещение посевов из северо-восточных провинций на север и запад в полузасушливые и засушливые провинции Внутренней Монголии и Xinjiang. Аналогичная ситуация отмечена в США, Аргентине и многих других странах. В сочетании со значительной изменчивостью по годам погодных условий, особенно повышением температуры и непредсказуемости выпадения осадков, это создает для подсолнечника значительные проблемы [36].

У подсолнечника наибольшая чувствительность к тепловому стрессу (свыше $25^{\circ} \mathrm{C}$ ) отмечена в период с 12-го по 19-й день после начала цветения, а температура свыше $31{ }^{\circ} \mathrm{C}$ является уже критической. Даже при хорошей влагообеспеченности температура свыше $26{ }^{\circ} \mathrm{C}$ является выше оптимальной для жизнеспособности пыльцы [32]. Установлено, что в условиях Пакистана даже короткое воздействие высокой (свыше $35{ }^{\circ} \mathrm{C}$ ) температуры снижает урожайность на $40 \%$, а масличность на $30 \%$ [37]. В результате проведенного отбора самоопыленных линий подсолнечника были выделены высокопродуктивные комбинации экспериментальных гибридов, обладающие повышенной гаметофитной толерантностью к тепловому стрессу. Такие гибриды имели пониженную проницаемость клеточных мембран, что позволяло проводить отбор перспек- 
тивных форм на стадии семядольных листьев [37].

У подсолнечника сроки посева позволяют избежать водного и теплового стресса в фазе цветения и налива семян. По этой причине в некоторых Средиземноморских странах подсолнечник высевается осенью и зимой и дает более высокий урожай по сравнению с весенним сроком посева $[32 ; 38 ; 39 ; 40]$. В более северных регионах возможной альтернативой подзимнему посеву является отбор сортообразцов, толерантных к холоду и небольшим заморозкам на первых стадиях роста $[41 ; 42 ; 43]$. По данным некоторых исследователей, признак толерантности к холоду у прорастающих семян зависим от их масличности [44], а также от содержания в масле линолевой кислоты [45]. Отмечено также наличие значительной изменчивости по холодостойкости, в том числе среди сортообразцов селекции ВНИИМК [42; 46].

Помимо перечисленных методических приемов селекции, достаточно простая модель адаптации к изменяющимся условиям внешней среды заключается в выведении и внедрении сортообразцов с укороченным периодом вегетации [32]. Это также способствует сохранению высокой продуктивности подсолнечника в более нестабильных и многонаправленных изменениях климата [47].

В повышении стабильности производства подсолнечника большое значение имеет устойчивость к основным патогенам [48]. В последние годы под влиянием изменения климата наблюдается сдвиг в распространении болезней по сравнению с предыдущим 20-летним периодом. Поскольку почти весь период вегетации подсолнечника протекает при экстремально высоких температурах, это обстоятельство может замедлить или даже остановить развитие некоторых патогенов, оптимальная температура для которых лежит в диапазоне $15-25^{\circ} \mathrm{C}$ [32].

Так, например, для фомопсиса чередование нескольких последовательных дней с температурой более $32{ }^{\circ} \mathrm{C}$ являются летальными. В то же время для пепельной гнили стимулирующим фактором является сочетание низкого содержания влаги в почве с высокой $\left(28-30{ }^{\circ} \mathrm{C}\right)$ температурой воздуха. Фомоз лучше развивается и вызывает преждевременное созревание подсолнечника при засушливых условиях, складывающихся после цветения.

Исследования, проведенные в Болгарии, показали, что за последние 20 лет произошло резкое уменьшение поражения подсолнечника ложной мучнистой росой, фомопсисом и серой гнилью. В то же время значительно увеличилось поражение альтернарией, фомозом, ржавчиной, сухой и пепельной гнилью, а также вертициллезом [33]. В связи с этим требуется быстрая перестройка селекционных программ в направлении отбора засухоустойчивых биотипов, генетически устойчивых к новому комплексу болезней $[47 ; 48 ; 49 ; 50]$. При этом важное значение имеет отбор генотипов, которые сохраняют стабильность изучаемых признаков в новых агроэкологических условиях [49].

В связи с глобальным потеплением граница возможного выращивания подсолнечника будет сдвигаться на север с интенсивностью 120-150 км на каждый градус увеличения температуры. Предположительно, к 2050 г. ультраранние сортообразцы подсолнечника будут вызревать на 79 \% площадей в Великобритании [32]. В новых регионах выращивания, где отсутствует патогенное начало, в первый период внедрения подсолнечника инфекционная нагрузка болезней будет меньше. Предполагается, что за счет этого сложатся более благоприятные условия для выращивания подсолнечника.

Адаптация подсолнечника к выращиванию в новых условиях будет проходить в сочетании приемов обработки почвы, применения удобрений и защиты растений. Главными факторами риска при развитии болезней являются накопление 
патогенного начала при нарушении научно обоснованного чередования культур в севообороте, использование технологии нулевой или минимальной обработки почвы в дополнение к благоприятным для заражения погодным условиям [51]. При нулевой или минимальной обработке почвы многие возбудители болезней остаются на поверхности и создают инфекционный фон. Глубокая пахота и перемещение зараженных растительных остатков в глубокие слои почвы препятствуют их появлению на поверхности, уменьшая тем самым нагрузку патогенов на растение подсолнечника [52]. Такой прием наиболее эффективен для защиты от фомопсиса, склеротинии, фомоза, ложной мучнистой росы, ржавчины и других болезней. Даже севооборот как система борьбы с болезнями не полностью выполняет свое значение, если традиционная технология обработки почвы нарушается и заменяется технологией поtill.

Наибольшая эффективность традиционной технологии возделывания подсолнечника с использованием глубокой вспашки отмечена во многих исследованиях $[53 ; 54 ; 55 ; 56]$. Установлено, что в условиях Румынии обычная глубокая пахота на 28-30 см обеспечивает получение оптимального сложения почвенного горизонта в то время, как на вариантах c no-till наблюдается наибольшая плотность поч-

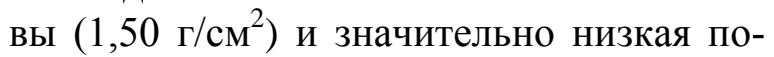
ристость. Запасы доступной влаги на период посева в слое 0-50 см также были минимальными на варианте с no-till $\left(706 \mathrm{~m}^{3} /\right.$ га) против $\left(805 \mathrm{~m}^{3} / г а\right)$ на пахоте [53]. Засоренность на вариантах с no-till увеличивалась до 80,2 \% в начальный период вегетации и до 379,4 \% перед уборкой, в результате чего снижение урожайности на варианте с no-till достигало 3,8 ц/га [53].

Хотя в Аргентине подсолнечник по технологии no-till выращивается на $33 \%$ от общей посевной площади, отмечается, что эта технология «не очень подходит для подсолнечника из-за плохого роста корней в уплотненной почве» [54]. Кроме того, внесение удобрений на нужную глубину в вариантах c no-till эффективно, но трудно выполнимо.

Во Франции посев подсолнечника производится по глубокой вспашке на $72 \%$ площади, а по технологии no-till только на $2 \%$ площади. Зависимость урожайности от глубины основной обработки на юго-западе Франции такая: по мелкой вспашке - 2,28 т/га, среднеглубокой $-2,34$ т/га и глубокой - 2,73 т/га [55]. Наиболее актуальным для улучшения технологии возделывания подсолнечника во Франции считается решение проблемы лучшего водоснабжения. Это требует более тщательного подбора сроков посева, густоты стояния растений, уточнения норм внесения удобрений и подбор сортообразцов с оптимальной продолжительностью периода вегетации. В 2007 г. парламент Франции принял закон, предусматривающий снижение количества пестицидов, применяемых на подсолнечнике, на 50 \% к 2017 г. [55]. Это подразумевает разработку усовершенствованной технологии возделывания подсолнечника, обеспечивающей эффективный контроль над болезнями без опрыскивания растений в период вегетации, особенно перед созреванием.

Под подсолнечник во Франции вносится значительно меньше азотных удобрений, чем под другие культуры (36 кг/га $\mathrm{N}$ против 97-189 кг/га). По этой причине суммарный выброс в атмосферу парниковых газов $\left(\mathrm{NO}_{3} ; \mathrm{NH}_{3} ; \mathrm{CO}_{2}\right)$ у подсолнечника в 3,0-3,6 раз меньше [32]. При средней урожайности подсолнечника во Франции 2,39 т/га, а озимого рапса 3,28 т/га выделение парниковых газов у посевов подсолнечника составляет 376 кг/т, а у озимого рапса - 812 кг/т, или в 2,2 раза больше. Как культура, значительно меньше влияющая на выделение парниковых газов, подсолнечник должен обратить на себя большее внимание в бу- 
дущей системе сельскохозяйственного производства [32].

Совершенствование технологии возделывания подсолнечника невозможно при грубом нарушении научно обоснованного чередования культур в севообороте. Подсолнечник не должен высеваться на том же поле как минимум 5-6 лет [57]. К сожалению, экономические обстоятельства заставляют производителей сокращать этот период, ухудшая многие факторы внешней среды, необходимые для получения высокой урожайности. Севооборот является наиболее эффективным способом сохранения доступной для подсолнечника влаги в нижних горизонтах почвы и занимает ведущее место по эффективности в интегрированной системе борьбы с сорняками.

На основе изучения закономерностей водопотребления и минерального питания сорных растений было установлено, что минимальное расстояние между корнями сорных и культурных растений, при котором не отмечено конкуренции за воду и питательные вещества, составляет: для растворимых форм азота $-8 \mathrm{~cm}$, фосфора $-0,2$ см и воды -8 см [57]. Эти экспериментальные данные послужили обоснованием для разработки специального приема минимальной обработки почвы (strip-tillage), который используется для культур широкорядного посева. Заключается он в двухслойной обработке, а именно: на поле формируются полосы шириной 25-30 см, вспаханные на ту же глубину. В центр полос вносятся локально удобрения и высеваются семена подсолнечника. Необработанные участки посева (неудобренные и невспаханные), но обработанные гербицидами, позволяют уменьшить засоренность и повысить эффективность использования удобрений [57]. Эффективность такой технологии объясняется тем, что сорняки, особенно щирица и марь белая очень чувствительны к нехватке элементов минерального питания, прежде всего фосфора.
В опытах югославских ученых был проведен анализ состояния выполнения основных технологических операций при возделывании подсолнечника [58]. Установлено, что на $74 \%$ площадей под этой культурой удобрения вообще не вносятся, а на остальных применяется их мизерное количество - 11; 7 и 6 кг/га NPK соответственно. Технология включает такие грубые нарушения, как весновспашка (на $32 \%$ площадей), севооборот короче 3 лет (20\%), поздний посев (12\%), поздняя уборка $(20 \%)$. Приводятся данные по влиянию нарушений технологических приемов на урожайность подсолнечника. Так, например, нарушение севооборота (3 и меньшее количество лет) снижает урожайность на 410 кг/га, в то время как использование 6-польного севооборота дает прибавку до 170 кг/га. Использование весновспашки приводит к недополучению урожайности от 150 до 340 кг/га в зависимости от условий года, посев после сои от 700 до 750 кг/га. Задержка сроков посева на каждые 10 суток от оптимальных снижает урожайность на 100 кг/га, а посев с опозданием на месяц - 500 кг/га. Запаздывание с уборкой способствует недополучению от 20 до 280 кг/га, а в отдельные годы - от 60 до 680 кг/га [58].

Приведенные примеры являются убедительными свидетельствами в пользу соблюдения всех без исключения основных научно обоснованных элементов технологии возделывания подсолнечника. Попытки внедрения новых элементов интенсификации производства подсолнечника на фоне грубых нарушений агротехники никогда не приводили и не приведут к увеличению урожайности. Так, например, в Индии в главных зонах производства подсолнечника эта культура высевается на одном и том же месте как монокультура без соблюдения севооборота [59]. В таких условиях внедрение межлинейных гибридов как современного наукоемкого фактора интенсификации производства на 80 \% посевных площадей подсолнечника в Индии не оказало 
существенного влияния на урожайность. Средняя продуктивность подсолнечника с площади 2,1 млн га составила в 2004 г. 0,57 т/га, что является самым низким показателем в мире [60]. В последние годы урожайность подсолнечника в Индии возросла до 0,75 т/га на фоне резкого сокращения посевных площадей до 0,55 млн га, однако также остается самой низкой в мире [61].

Значение и состояние соблюдения технологии выращивания подсолнечника можно оценить при сравнении потенциальной и реальной продуктивности современных селекционных достижений. Так, например, по данным болгарских исследователей, потенциал урожайности отечественных гибридов составляет от 4,3 до 6,0 т/га, однако в производстве обычно получают от 1,5 до 3,0 т/га, в среднем 2,3 т/га на площади более 800 тыс. га [62; 63]. Аналогичная ситуация отмечена в Румынии, где в 2014 г. на площади 990 тыс. га средняя урожайность составила 2,13 т/га [64].

Большие проблемы при возделывании подсолнечника из-за нарушения севооборота наблюдаются также в Китае и Турции, вследствие чего произошло быстрое распространение заразихи, накопление инфекционного начала склеротинии и других опасных болезней [65; 66]. В Российской Федерации площадь посева подсолнечника в среднем за 2011-2015 гг. составила 7,1 млн га, что в 2,9 раза больше, чем за период 1986-1990 гг. [67]. В последние годы (2018-2020 гг.) происходило дальнейшее увеличение посевной площади под подсолнечником, которая достигла 8,8-9,0 млн га. Таким образом, в настоящее время в России фактическая площадь посева подсолнечника в 3,6 раза превышает научно обоснованный уровень, необходимый для соблюдения севооборота. Вследствие этого подсолнечник возвращается на прежнее место максимум через 3-4 года, вместо 8-10 лет, необходимых для соблюдения требований прогрессивной технологии возделывания.
В ситуации, когда практически повсеместно наблюдаются грубые нарушения агротехники выращивания подсолнечника, все чаще стали использоваться различные биостимуляторы и микроудобрения $[68 ; 69 ; 70 ; 71 ; 72]$. Однако экономическая целесообразность их применения в большинстве случаев остается неподтвержденной. Главной причиной этому являются резкие колебания условий окружающей среды, в особенности по количеству выпадающих осадков и температуре воздуха, которые нейтрализуют различия между вариантами обработки. Так, например, в опытах сербских исследователей изучалось влияние биостимуляторов на качество семян, урожайность и масличность подсолнечника. Влияние всех вариантов обработки семян было слабым и не существенным для снижения урожайности, масличности и сбора масла с гектара [68]. При изучении реакции новых болгарских гибридов на обработку микроудобрениями, биостимуляторами и применение минеральных удобрений было установлено, что «все варианты обработки имели нулевой эффект на урожайность» [69]. Более того, урожайность на контроле была выше, чем на всех вариантах обработки. Авторы исследований объясняют такое явление тем, что растения с более мощной вегетативной массой, образовавшейся в вариантах обработки, подвергаются более сильному стрессу при попадании в экстремальные условия среды.

Резкие колебания по количеству осадков в годы проведения исследований нивелировали различия между вариантами обработки. Минеральные удобрения в дозе $\mathrm{N}_{60} \mathrm{P}_{120} \mathrm{~K}_{80}$ также не оказывали существенного влияния на урожайность. В таких условиях значительно больший эффект на урожайность имел фактор густоты стояния растений [69].

Широкораспространенное мнение о безусловной эффективности боросодержащих микроэлементов для получения высокой урожайности подсолнечника 
также не подтверждается в ряде зарубежных исследований [70; 71].

Существенные изменения в технологии возделывания подсолнечника начались после разработки и внедрения системы Clearfield, позволяющей эффективно контролировать засоренность посевов и уменьшить поражение заразихой. По такой технологии подсолнечник выращивался в 2008 г. в России на $1 \%$ от общей площади посева, в Болгарии - $33 \%$, Румынии $-16 \%$, Венгрии - $17 \%$, Сербии $11 \%$, Словакии - 6\%, Украине - $3 \%$, Испании - 2 \% и Турции - $24 \%$ [72]. Несмотря на высокую эффективность данной системы, установлено, что сразу после подсолнечника, возделываемого по системе Clearfield, нельзя сеять такие культуры, как озимый рапс и сахарную свеклу [73]. Обеспечивая некоторый контроль за заразихой, технология Clearfield способствовала резкому увеличению расообразовательного процесса у этого паразита при широком ее использовании [74]. С началом внедрения высокоспецифических типов гербицидов по системе Clearfield также резко возрастало количество устойчивых к ним сорных и культурных растений, что создает угрозу для обычной технологии возделывания подсолнечника. Созданная природой и размноженная человеком устойчивая популяция подсолнечника стала быстро распространяться посредством переноса пыльцы, всходов падалицы и за счет других организационно-технических мероприятий. Установлено, что перенос устойчивых растений может происходить на большие расстояния в течение даже одного сезона [75; 76].

Однако отдаленные неблагоприятные последствия использования технологии Clearfield в настоящее время обычно не принимаются во внимание [77; 78]. В ряде зарубежных стран прирост урожайности подсолнечника за счет селекционного вклада в последние 30 лет составляет от 1,0 до $1,3 \%$ в год [74; 79]. В России в результате структурной перестройки эко- номики и общественно-политического уклада жизни урожайность в период 2011-2015 гг. составила 1,35 т/га, что всего на 0,07 т/га больше, чем за период 1986-1990 гг. [67]. Таким образом, ежегодный прирост урожайности подсолнечника, если сравнивать только эти периоды, составил $0,2 \%$, что в 5,0-6,5 раз меньше, чем в зарубежных странах. Однако при этом следует учитывать значительное снижение урожайности в России в промежуточном периоде между 19861990 гг. и 2011-2015 гг. Так, например, по сравнению с доперестроечным периодом (1986-1990 гг.) снижение урожайности составило [67]:

- в период 1991-1995 гг. - 0,23 т/га $(-18,0 \%)$

- в период 1996-2000 гг. - 0,43 т/га $(-67,2 \%)$

- в период 2001-2005 гг. - 0,29 т/га $(-22,6 \%)$

- в период 2006-2010 гг. - 0,16 т/га $(-12,5 \%)$

Суммируя недобор урожайности за отмеченный период и учитывая прибавку в 0,07 т/га за период 2011-2015 гг., получаем средневзвешенный показатель недобора урожайности подсолнечника за 19912015 гг., равный 0,21 т/га (-0,16\%).

Таким образом, в Российской Федерации, несмотря на активное внедрение новейших селекционных достижений в форме зарубежных гибридов подсолнечника ведущих мировых учрежденийоригинаторов, произошло существенное снижение урожайности. Причина этого кроется не в высоком качестве зарубежных селекционных достижений, а исключительно в грубейших нарушениях технологии возделывания подсолнечника в этот переходный период. Аналогичный процесс происходил и в других странах, где практически повсеместно грубо нарушали научно обоснованные сроки чередования культур в севообороте, а также все остальные прогрессивные приемы возделывания подсолнечника [58; 62; 63; $64 ; 80]$. В итоге получили феномен широ- 
кого распространения новых, более агрессивных рас заразихи, которой в настоящее время пытаются нейтрализовать посредством использования Clearfieldтехнологии [81].

Однако проведенные в Турции широкомасштабные опыты по анализу деятельности 571 хозяйства провинции Тракия в условиях сильного поражения подсолнечника заразихой показали, что средняя урожайность IMI-гибридов практически не отличалась от средней урожайности восприимчивых гибридов: 1,69 против 1,55 т/га соответственно [66]. Более того, рентабельность производства восприимчивых гибридов оказалась выше, чем у гибридов, выращиваемых по Clearfield-технологии. Основной причиной этому явилась высокая стоимость IMI-гербицидов, создающая одну из главных проблем в производстве подсолнечника в Турции [82]. Наибольшую урожайность $(1,93$ т/га) и максимальную чистоту прибыль обеспечили гибриды, обладающие генетической устойчивостью к заразихе.

Проведенное при этом социологическое исследование показало, что при использовании IMI-гибридов большинство фермеров (72 \%) считают главным их преимуществом способность легкого контроля засоренности посевов. Другие факторы, такие как повышенная устойчивость к заразихе и более высокая урожайность, имели значительно меньшее влияние на выбор гибридов (16,2 и 7,8 \% соответственно). Остальные 4,0\% респондентов назвали некоторые другие факторы влияния [66]. Главной причиной выбора генетически устойчивых к заразихе гибридов фермеры назвали более высокую потенциальную урожайность $(43,3 \%)$, заразихоустойчивость $(31,8 \%)$, а также высокую масличность (16,5\%). И, наконец, возделывание восприимчивых к заразихе гибридов продолжается по причине их относительно высокой урожайности $(67,5 \%)$, а также за счет других сопутствующих факторов привлекательности $(25,0 \%)$.

При интерпретации результатов данного исследования следует однако иметь ввиду, что производство подсолнечника в Турции - дорогая и менее выгодная отрасль по сравнению с другими полевыми культурами [82]. Соотношение цен на товарный подсолнечник и пшеницу в настоящее время меньше, чем 2 : 1 , а в период 1990-2005 гг. в провинции Тракия оно достигало более $2,5: 1$. За счет этого происходил рост посевных площадей под подсолнечником [83]. Поскольку подсолнечник в Турции имеет меньшую рентабельность как в условиях богарного, так и орошаемого земледелия, по сравнению с пшеницей, кукурузой и рисом, то фермеры предпочитают вносить под него ограниченное количество минеральных удобрений и не всегда имеют возможность строго соблюдать все элементы прогрессивной технологии выращивания.

Селекционеры по подсолнечнику, разрабатывая модели (идеатипы) сортов и гибридов, учитывают характеристики условий внешней среды, начиная от типа почвы, продолжительности периода вегетации, количества и распределения осадков, максимальной и минимальной температуры, а также влияние других лимитирующих факторов [84]. В связи с глобальным потеплением климата особое внимание обращается на толерантность к биотическим и абиотическим стрессам, особенно к тепловому стрессу в период цветения $[34 ; 47 ; 85 ; 86]$. Помимо этого, происходит постоянная перестройка селекционных программ в направлении повышения устойчивости к основным патогенам и заразихе [33; 78; 81], большое внимание уделяется селекции на качество семян и масла [49; 77]. Эффективное решение таких задач, по мнению зарубежных исследователей, будет требовать существенного повышения уровня селекции, открытия и использования новых источников исходного материала, полученных с помощью методов 
межвидовой гибридизации и мутагенеза [47; 87]. Потребуется также внедрение новых методов и технологий ускорения селекционного процесса с использованием генетических маркеров. Изменятся также взаимоотношения селекционеров необходим более интенсивный обмен исходным материалом и развитие совместных программ. Процесс селекции изменится в психологическом плане: если раньше он в значительной степени зависел от усилий одного человека, то теперь он будет зависеть от усилий, основанных на командной работе [47].

Однако прогресс селекционной технологии не позволяет получить ощутимого экономического эффекта на бедных почвах, а также при грубом нарушении научно обоснованных агротехнических приемов. Поэтому внедрение новейших селекционных достижений должно идти не впереди, а вслед за внедрением передовых элементов агротехники.

\section{Список литературы}

1. Пустовойт В.С. Селекция и семеноводство подсолнечника // Подсолнечник. - Краснодар, 1940. - С. 7-43.

2. Семихненко П.Г. Фазы вегетации и условия, определяющие масличность и налив семян подсолнечника // Сборник работ по масличным культурам. - Майкоп, 1966. - Вып. 3. - С. 63-70.

3. Пустовойm В.С. Подсолнечник (монография). - М.: Колос, 1975. - 592 с.

4. Кондратьев В.И., Семихненко П.Г. Сроки посева и площади питания подсолнечника // Материалы $7^{\text {й }}$ Международной конференции по подсолнечнику. - Краснодар, 27 июня - 3 июля 1976. - М.: Наука, 1978. - С. 251-254.

5. Островский В.Б., Карастан Д.И. Регулирование густоты стояния растений подсолнечника в зависимости от запасов влаги в почве // Материалы $7^{\underline{\underline{n}}}$ Международной конференции по подсолнечнику. - Краснодар, 27 июня - 3 июля 1976. М.: Наука, 1978. - С. 264-266.

6. Тишков Н.М. Развитие исследований по земледелию и растениеводству // История научных исследований во ВНИИМКе за 90 лет. - Краснодар, 2003. - С. 214-238.

7. Пустовойт В.С. Селекция и семеноводство подсолнечника // Агробиология. - 1956. - № 1. C. 9-17.
8. Пустовойт В.С. Итоги работ по селекции и семеноводству подсолнечника за 1912-1961 годы // Сб.: Генетика - сельскому хозяйству. - М., 1963. С. 372-386.

9. Онищенко М.A. Семеноводство подсолнечника и задачи по его улучшению // Сб.: Селекция и семеноводство технических культур. - М.: Колос. 1973 . - С. 20-25.

10. Пустовойт В.С. Руководство по селекции и семеноводству масличных культур. - М.: Колос, 1967. $-351 \mathrm{c}$.

11. Пустовойт В.С. Результаты работ по селекции и семеноводству подсолнечника // Селекция и семеноводство. - 1960. - № 5. - С. 48-55.

12. Пустовойт В.С. Приемы выращивания высококачественных семян подсолнечника // Селекция и семеноводство. - 1961. - № 1. - С. 21-23.

13. Пустовойт В.С. Селекция и семеноводство подсолнечника // Бюл. науч.-тех. информ. по масл. культ. ВНИИМК. - 1967. - Ноябрь. - С. 9-18.

14. Пустовойт В.С., Онищенко М.А. Система семеноводства подсолнечника и ее эффективность // Сб.: Селекция и семеноводство масличных культур. - Краснодар, 1972. - С. 23-26.

15. Пустовойт В.С., Миронов Е.К. Сроки уборки семенных участков подсолнечника // Сб.: Селекция и семеноводство масличных культур. Краснодар, 1972. - С. 27-34.

16. Шепетина Ф.А., Мулинский В.A. Урожайные свойства семян подсолнечника в зависимости от места их репродуцирования // Сб.: Селекция и семеноводство масличных культур. - Краснодар, 1972. - C. 76-81.

17. Шепетина Ф.А. Пути дальнейшего повышения урожайных качеств семян подсолнечника // Бюл. науч.-тех. инфор. по масл. культ. - Краснодар, 1973. - Вып. 4. - С. 47-51.

18. Шепетина Ф.А. Влияние экологических условий на качество семенного материала подсолнечника // Материалы $7^{\underline{\underline{n}}}$ Международной конференции по подсолнечнику. - Краснодар, 27 июня - 3 июля 1976 г. - М.: Колос, 1978. - С. 228 231.

19. Шепетина Ф.А., Литвиненко В.А. Урожай и масличность подсолнечника в зависимости от места выращивания семян // Бюл. науч.-тех. инфор. по масл. культ. ВНИИМК. - 1975. - Вып. 4. C. 31-34.

20. Белевцев Д.Н. Особенности формирования семян подсолнечника с высокими урожайными свойствами // Селекция и семеноводство. - 1973. № $1 .-$ С. 58-63.

21. Белевиев Д.Н., Макарова В.Ф. Высокоэффективные способы повышения урожайных свойств семян подсолнечника // Науч.-тех. бюл. ВНИИМК. - 1991. - Вып. 4 (115). - С. 40-42.

22. Жученко А.А. Адаптивная система селекции растений. - М.: Агрорус, 2001. - Т. 1. - 719 с. 
23. Дьяков А.Б. Этапы разработки методов селекции и семеноводства сортов подсолнечника академиком В.С. Пустовойтом // История научных исследований во ВНИИМКе за 90 лет. - Краснодар, 2003. - С. 8-12.

24. Дьяков А.Б. Метод селекции сортов подсолнечника академика В.С. Пустовойта и варианты его описания в разных публикациях // Масличные культуры. Науч.-тех. бюл. ВНИИМК. Вып. 2 (144-145). - 2010. - С. 36-48.

25. Пустовойт B.C. Методы работы в области выведения высокомасличных сортов подсолнечника // Тр. Всес. науч.-метод. совещ. по масл. культ. 16-21 июня 1946 г. - Краснодар: Книгоиздательство, 1946. - С. 231-251.

26. Пустовойт В.С. Результаты и перспективы селекции и семеноводства подсолнечника // Тр. Bсес. науч.-произв. совещ. по масл. культ. 25-29 июня 1951 г. - Краснодар: Советская Кубань, 1952. - C. 224-242.

27. Пустовойт В.С., Дьяков А.Б. Урожайность подсолнечника и пути ее повышения в процессе селекции // Селекция и семеноводство. - 1971. № 1. - C. 25-30.

28. Пустовойт В.С., Дьяков А.Б. О селекции подсолнечника на содержание белка в семенах // Вестник с.-х. науки. - 1972. - № 7. - С. 11-15.

29. Дьяков А.Б., Бойко Ю.Г., Васильева Т.А. Возможности повышения интенсивности отборов из перекрестноопыляющихся популяций // Масличные культуры. Науч.-тех. бюл. ВНИИМК. 2003. - Вып. 2 (129). С. 3-24.

30. Anaschenko A.V. The initial material for sunflower heterosis breeding // Proc. of $6^{\text {th }}$ Intern. Sunfl. Conf. Bucharest, Romania, 22-24 July, 1974. - P. 391-393.

31. Seiler G., Jan C.C. Basic information // Genetics, genomics and breeding of sunflower / $\mathrm{Hu} \mathrm{J}$., Seiler G. (Eds). - USA, 2010. - P. 1-50.

32. Debaeke P., Casadebaig P., Flenet F., Langlade N. Sunflower crop and climate change in Europe: vulnerability, adaptation and mitigation potential // Proc. of $19^{\underline{\underline{t h}}}$ Intern. Sunfl. Conf., Turkey, Edirne, 29 May - 2 June, 2016. - P. 71-87.

33. Encheva $V$. Changes in the pathogenic composition, attacking the oil sunflower in Bulgaria // Proc. of $19^{\text {th }}$ Intern. Sunfl. Conf., Turkey, Edirne, 29 May -2 June, 2016. - P. 391-393.

34. Gurkan H., Bayractar N., Bulut H., Kocak N., Eskioglu O., Demircan M. The effect of climate factors on the yield of sunflower and sunflower yield predictions based on climate change projections: example of Marmara region // Proc. of 19 $9^{\text {th }}$ Intern. Sunfl. Conf., Turkey. Edirne, 29 May - 2 June, 2016. - P. 919-929.

35. Vick B.A., Hu J. Future prospects // Genetic, genomics and breeding of sunflower / Hu J., Seiler G. (Eds). - USA, 2010. - P. 313-335.
36. Demir I. Determination of the yield and yield components performance of some sunflower (Helianthus annuus L.) under rainfed conditions // Proc. of $19^{\text {th }}$ Intern. Sunfl. Conf., Edirne, Turkey, 29 May -2 June, 2016. - P. 985-992.

37. Khan M., Kausar M., Rauf S., Hussain M. Evaluation of sunflower (Helianthus annuus L.) single cross hybrids under heat stress condition // Proc. of $19^{\text {th }}$ Intern. Sunfl. Conf., Turkey, Edirne. 29 May -2 June. 2016. - P. 118-128.

38. Tarik A.J., Gursham S.G. Sunflower cultivation in Iraq // Proc. of $6^{\text {th }}$ Intern. Sunfl. Conf., Romania, Bucharest, 22-24 July, 1974. - P. 83-84.

39. Downes R.W. Breeding sunflowers for mediterranean type climatic conditions // Proc. of $6^{\text {th }}$ Intern. Sunfl. Conf., Romania, Bucharest, 22-24 July, 1974. - P. 395-399.

40. Boujghagh $M$. Comportement de dix genotypes de tournesol en semis d' hiver dans trios sites pedoclimatiques marocains // Helia. - 1993. - V. 16. No 19. - P. 31-44.

41. Синская E.Н. Направление и исходный материал в селекции масличных культур // Тр. науч.методич. совещ. по масл. культ. 16-21 июня 1946. Краснодар, 1946. - С. 89-111.

42. Gimeno $V$. Variation in rate of germination at low temperature as a basic for selection in sunflowers // Proc. of $6^{\text {th }}$ Intern. Sunfl. Conf., Romania, Bucharest, 22-24 July. 1974. - P. 471-472.

43. Macchia M., Benvenuti M., Baldanzi M. Temperature requirements during germination in sunflower // Proc. of $11^{\text {th }}$ Intern. Sunfl. Conf., Argentina, Mar del Plata, March 10-13, 1985. - V.1. - P. 93-97.

44. Sin G., Hera C., Pintilie C. Improved cultural practices for sunflower hybrids // Proc. of $7^{\text {th }}$ Intern. Sunfl. Conf., USSR, Krasnodar 27 June - July 3, 1976. - V. 2. - P. 19-26.

45. Downes R.W. Factors affecting germination of sunflower under low temperature conditions // Proc. of $11^{\text {th }}$ Intern. Sunfl. Conf., Argentina, Mar del Plata, Match 10-13. 1985. - V.1. - P. 87-92.

46. Клюка В.И., Арасланова Н.М. Использование камер искусственного климата для оценки селекционного материала подсолнечника по ранневсхожести и скороспелости // Сб. научных работ: Использование фитотрона в селекции масличных культур. - Краснодар, 1984. - С. 4144.

47. Dozet B. Sunflower breeding achievement and challenges // Proc. of Intern. Symp. on confection sunflower technology and production, Wuyuan, China, August 8-10, 2018. - P. 55.

48. Kaya Y., Beser N. Confectionery sunflower hybrid breeding studies in Turkey: current and future strategies // Proc. of Intern. Symp. on confection sunflower technology and production. Wuyuan. China, August 8-10, 2018. - P. 51-52.

49. Hladni N., Miklic V., Jocic S., Miladinovic D., Dimitrijevic A., Jockovic M., Cvejic S., Dedic B., 
Marjanovic A. Achievements and future prospects of NS confectionery breeding program // Proc. of Intern. Symp. on confection sunflower technology and production. Wuyuan, China, August 8-10, 2018. - P. 7778.

50. Aytac S., Arslanoglu S., Yigen C. Some morphological characteristics of confectionary sunflower genotypes obtained through selection breeding // Proc. of $19^{\text {th }}$ Intern. Sunfl. Conf. - Turkey. - Edirne. - May 29 - June 2. - 2016. - P. 1102-1105.

51. Byamukama E. Major sunflower diseases and their management in USA: A review // Proc. of Intern. symp. on confection sunflower technology and production, Wuyuan, China, August 8-10, 2018. - P. 27.

52. Masirevic S. Latest sunflower diseases research progress and management // Proc. of Intern. symp. on confection sunflower technology and production, Wuyuan, China, August 8-10, 2018. - P. 3334.

53. Sin G., Petcu G., Ionita S., Popa M. The influence of soil tillage and sowing technology on sunflower production // Proc. of $15^{\text {th }}$ Intern. Sunfl. Conf., France, Toulouse, June 12-15, 2000. - V.1. - P. 150155.

54. Baumer C.R., Gonzalez N., Devito C. Fertilization profunda del girasol en siemera directa en la region Pampeana Argentina // Proc. of $15^{\text {th }}$ Intern. Sunfl. Conf., France, Toulouse, June 12-15, 2000. V. 1. - P. 159-164.

55. Flenet F., Debacke P., Casadebaig P. Could a crop model be useful for improving sunflower crop management // Proc. of $17^{\text {th }}$ Intern. Sunfl. Conf., Spain, Cordoba, June 8-12, 2008. - V. 1. - P. 13-18.

56. Marshall M.W., Al-Khatib K. Gene flow, growth and competitiveness of imazethapyr-resistant common sunflower (Helianthus annuus L.) // Proc. of $22^{\underline{t} \text { th }}$ Sunflower research workshop, Fargo, USA. January 18-19, 2000. - P. 150-153.

57. Bonary E., Vannozzi G.P., Benvenuti A., Baldini M. Modern aspects of sunflower cultivation techniques // Proc. of $13^{\text {th }}$ Intern. Sunfl. Conf., Italy, Pisa, September 7-11, 1992. - P. 3-51.

58. Crnobarac J., Skoric D., Dusanic N., Marinkovic B. Effect of cultural practices on sunflower yields in a period of several years in FR Yugoslavia // Proc. of $15^{\text {th }}$ Intern. Sunfl. Conf., France, Toulouse, June 12-15. 2000. - V. 1. - P. 13-18.

59. Giriray K. Present status and prospects of sunflower cultivation in India // Helia. -1991. - V. 14. No 15. - P. 113-116.

60. Manivannan N., Muralidharan $V$., Ravindirakumar M. Association between parent and progeny performance and their relevance in heterosis breeding of sunflower // Proc. of $16^{\text {th }}$ Intern. Sunfl. Conf., USA, Fargo, August 29 - September 2, 2004. P. 581-584.

61. Sheoran R.K. Rerspective and challenges to develop high yielding resistant and oil quality sun- flower hybrids in India // Proc. of $19^{\text {th }}$ Intern. Sunfl. Conf., Turkey, Edirne, May 29 - June 2, 2016. - P. 324-330.

62. Georgiev G., Encheva V., Nenova N., Encheva Y., Valkova D., Peevska P., Penchev E. Production potential of new sunflower hybrids developed at Dobrudzha agricultural institute - General Toshevo // Proc. of $19^{\text {th }}$ Intern. Sunfl. Conf., Turkey, Edirne, May 29 - June 2, 2016. - P. 441-453.

63. Hristova-Cherbadzhi M., Molle E. Evaluation of variation on sunflower single crosses. // Proc. of $19^{\text {th }}$ Intern. Sunfl. Conf., Turkey, Edirne, May 29 - June 2, 2016. - P. 583-592.

64. Jinga V., Paica A., Dudoiu R., Gradila M., Manole D., Giumba A. The behavior of some sunflower cultivars to the major pest agents in the southeastern area of Romania // Proc. of $19^{\text {th }}$ Intern. Sunfl. Conf., Turkey, Edirne, May 29 - June 2, 2016. - P. 809-815.

65. Zhang Y. Report of the development of the sunflower industry in Chine // Proc. of Intern. Symp. on confection sunflower: technology and production. China, Wuyuan, August 8-10, 2018. - P. 18-21.

66. Semenci A., Kaya Y., Sahin I., Citak N. Determination of the performances and adoption levels of sunflower cultivars based on resistance to broomrape in farm conditions in Thrace region // Helia. - 2010. V. 33. - No 53. - P. 69-76.

67. Бочковой А.Д., Перетягин Е.А., Хатнянский В.И., Камардин В.А., Кривошльков К.М. Подсолнечник: особенности сортовой политики в зависимости от почвенно-климатических, технологических и социально-экономических условий (обзор) // Масличные культуры. Науч.-тех. бюл. ВНИИМК. - 2018. - Вып. 2 (174). - С. 120-134.

68. Miklic V., Ovuka J., Balalic I., Hladni N., Cvejic S., Miladinov Z., Jocic S. Effect of biostimulators on seed quality, yield and oil content in sunflower // Proc. of $19^{\text {th }}$ Intern. Sunfl. Conf., Turkey, Edirne, 29 May - 2 June, 2016. - P. 1027-1036.

69. Milev G., Georgiev G., Peevska P. Effect of the plant density and foliar fertilization on the yield from new Bulgarian hybrids of sunflower (Helianthus annuus L.) // Proc. of $19^{\text {th }}$ Intern. Sunfl. Conf., Turkey, Edirne, 29 May - 2 June, 2016. - P. 10101018.

70. Castro C., Moreira A., Rodriques J. Sunflower response to water stress and boron application // Proc. of $15^{\text {th }}$ Intern. Sunfl. Conf., France, Toulouse, June 12-15, 2000. - V. 1. - P. 145-149.

71. Castro C., Brighenti A., Leite R., Oliveira F. Interaction of Boron supplied by soil with foliar sprays in sunflower // Proc. of $16^{\text {th }}$ Intern. Sunfl. Conf., USA, Fargo, August 29 - September 2, 2004. V. 1. - P. 343-346.

72. Alonso L.C. Sunflower in Spain: past and present trends in an international context // Proc. of $17^{\text {th }}$ Intern. Sunfl. Conf., Spain, Cordoba, June 8-12, 2008. P. 53-68. 
73. Suzer S., Buyuk H. Residual effects of spraying imidazolinone-famili herbicides on clearfield sunflower production from the point of view of crop rotation // Helia. - 2010. - V. 33. - No 52. - P. 2536.

74. Vear F. Classic genetics and breeding // Genetics, genomics and breeding of sunflower / $\mathrm{Hu}$ J., Seiler G., Kole C. (Eds). - USA, 2010. - P. 51-79.

75. Marshall M.W., Al-Khatib K. Gene flow, growth and competitiveness of imazethapyr-resistant common sunflower (Helianthus annuus L.) // Proc. of $22^{\text {th }}$ sunflower research workshop, USA, Fargo, January $18-19,2000$. - P. 150-153.

76. Marshall M.W., Massing R.A., Al-Khatib K. Imazethapyr resistant gene flow in sunflower // Proc. of sunflower research workshop, USA, Fargo, January $17-18,2001$. - P. 120-125.

77. Hladni N. Present status and future prospects of global confectionery sunflower production // Proc. of $19^{\text {th }}$ Intern. Sunfl. Conf., Turkey, Edirne, 29 May 2 June, 2016. - P. 47-60.

78. Bater B. Effects of IMI herbicides on controlling Orobanche in sunflower fields // Proc. of Intern. Symp. on Confection sunflower technology and production. China, Wuyuan, August 8-10, 2018. - P. 3738.

79. Беккер $X$. Селекция растений. - М.: Товарищество научных изданий КМК, 2015. - 425 с.

80. Hristova-Cherbadzhi M. Evaluation of variation on sunflower single crosses // Proc. of $19^{\text {th }}$ Intern. Sunfl. Conf., Turkey, Edirne, 29 May - June 2, 2016. P. 583-592.

81. Encheva J., Georgiev G., Valkova D., Encheva $V$. Development of sunflower hybrids resistant to herbisides // Proc. of $19^{\text {th }}$ Intern. Sunfl. Conf., Turkey, Edirne, May 29 - June 2, 2016. - P. 465-473.

82. Semerci A., Kaya Y., Sahin I., Citak N. Evaluation of the changes in the cost factors of sunflower produced in Thrace on the basis of the provinces in the research field and the sizes of enterprise // Helia. 2011. - V. 34. - No 54. - P. 147-158.

83. Kaya S.A., Durak S. Economic analysis of sunflower production in Turkey // Helia. - 2007. - V. 30. - No 47. - P. 105-114.

84. Luxita R., Gabriel A.F., Pacureanu J.M., Sava $E$., Victorita $M$. The behavior of sunflower hybrids in different environmental conditions in Romania // Proc. of $19^{\text {th }}$ Intern. Sunfl. Conf., Turkey, Edirne, 29 May - 2 June, 2016. - P. 827.

85. Peevska P., Georgiev G. A new Bulgarian sunflower hybrid Dea. // Proc. of $19^{\text {th }}$ Intern. Sunfl. Conf., Turkey. Edirne. May 29 - June 2, 2016. - P. 475-483.

86. Fernandez-Martinez J.M., Perez-Vich B., Velasco L. Sunflower. Oil crops // Handbook of plant breeding. / Vollmann J., Rajcan J. (Eds) - Springer. London, New York, 2009. - P. 155-232.

87. Christov $M$. Contribution of interspecific and intergeneric hybridization in sunflower breeding //
Proc. of Intern. Symp. on Confection sunflower technology and production, China, Wuyuan, August 8-10, 2018. - P. 61-62.

\section{References}

1. Pustovoyt V.S. Selektsiya i semenovodstvo podsolnechnika // Podsolnechnik. - Krasnodar, 1940. S. 7-43.

2. Semikhnenko P.G. Fazy vegetatsii i usloviya, opredelyayushchie maslichnost' i naliv semyan podsolnechnika // Sbornik rabot po maslichnym kul'turam. - Maykop, 1966. - Vyp. 3. - S. 63-70.

3. Pustovoyt V.S. Podsolnechnik (monografiya). M.: Kolos, 1975. - 592 s.

4. Kondrat'ev V.I., Semikhnenko P.G. Sroki poseva i ploshchadi pitaniya podsolnechnika // Materialy 7y Mezhdunarodnoy konferentsii po podsolnechniku. - Krasnodar, 27 iyunya - 3 iyulya 1976. - M.: Nauka, 1978. - S. 251-254.

5. Ostrovskiy V.B., Karastan D.I. Regulirovanie gustoty stoyaniya rasteniy podsolnechnika $\mathrm{V}$ zavisimosti ot zapasov vlagi v pochve // Materialy 7y Mezhdunarodnoy konferentsii po podsolnechniku. Krasnodar, 27 iyunya - 3 iyulya 1976. - M.: Nauka, 1978. - S. 264-266.

6. Tishkov N.M. Razvitie issledovaniy po zemledeliyu i rastenievodstvu // Istoriya nauchnykh issledovaniy vo VNIIMKe za 90 let. - Krasnodar, 2003. - S. 214-238.

7. Pustovoyt V.S. Selektsiya i semenovodstvo podsolnechnika // Agrobiologiya. - 1956. - № 1. - S. 9-17.

8. Pustovoyt V.S. Itogi rabot po selektsii i semenovodstvu podsolnechnika za 1912-1961 gody // Sb.: Genetika - sel'skomu khozyaystvu. - M., 1963. S. 372-386.

9. Onishchenko M.A. Semenovodstvo podsolnechnika i zadachi po ego uluchsheniyu // Sb.: Selektsiya i semenovodstvo tekhnicheskikh kul'tur. M.: Kolos. 1973. - S. 20-25.

10. Pustovoyt V.S. Rukovodstvo po selektsii i semenovodstvu maslichnykh kul'tur. - M.: Kolos, 1967. - $351 \mathrm{~s}$.

11. Pustovoyt V.S. Rezul'taty rabot po selektsii i semenovodstvu podsolnechnika // Selektsiya i semenovodstvo. - 1960. - № 5. - S. 48-55.

12. Pustovoyt V.S. Priemy vyrashchivaniya vysokokachestvennykh semyan podsolnechnika // Selektsiya i semenovodstvo. - 1961. - № 1. - S. 2123.

13. Pustovoyt V.S. Selektsiya i semenovodstvo podsolnechnika // Byul. nauch.-tekh. inform. po masl. kul't. VNIIMK. - 1967. - Noyabr'. - S. 9-18.

14. Pustovoyt V.S., Onishchenko M.A. Sistema semenovodstva podsolnechnika i ee effektivnost' // Sb.: Selektsiya i semenovodstvo maslichnykh kul'tur. Krasnodar, 1972. - S. 23-26. 
15. Pustovoyt V.S., Mironov E.K. Sroki uborki semennykh uchastkov podsolnechnika // Sb.: Selektsiya i semenovodstvo maslichnykh kul'tur. Krasnodar, 1972. - S. 27-34.

16. Shepetina F.A., Mulinskiy V.A. Urozhaynye svoystva semyan podsolnechnika $\mathrm{v}$ zavisimosti ot mesta ikh reprodutsirovaniya // Sb.: Selektsiya i semenovodstvo maslichnykh kul'tur. - Krasnodar, 1972. - S. 76-81.

17. Shepetina F.A. Puti dal'neyshego povysheniya urozhaynykh kachestv semyan podsolnechnika // Byul. nauch.-tekh. infor. po masl. kul't. - Krasnodar, 1973. - Vyp. 4. - S. 47-51.

18. Shepetina F.A. Vliyanie ekologicheskikh usloviy na kachestvo semennogo materiala podsolnechnika // Materialy 7y Mezhdunarodnoy konferentsii po podsolnechniku. - Krasnodar, 27 iyunya - 3 iyulya 1976 g. - M.: Kolos, 1978. - S. 228-231.

19. Shepetina F.A., Litvinenko V.A. Urozhay i maslichnost' podsolnechnika $\mathrm{v}$ zavisimosti ot mesta vyrashchivaniya semyan // Byul. nauch.-tekh. infor. po masl. kul't. VNIIMK. - 1975. - Vyp. 4. - S. 3134.

20. Belevtsev D.N. Osobennosti formirovaniya semyan podsolnechnika s vysokimi urozhaynymi svoystvami // Selektsiya i semenovodstvo. - 1973. № 1. - S. 58-63.

21. Belevtsev D.N., Makarova V.F. Vysokoeffektivnye sposoby povysheniya urozhaynykh svoystv semyan podsolnechnika // Nauch.-tekh. byul. VNIIMK. - 1991. - Vyp. 4 (115). S. $40-42$.

22. Zhuchenko A.A. Adaptivnaya sistema selektsii rasteniy. - M.: Agrorus, 2001. - T. 1. $-719 \mathrm{~s}$.

23. D'yakov A.B. Etapy razrabotki metodov selektsii i semenovodstva sortov podsolnechnika akademikom V.S. Pustovoytom // Istoriya nauchnykh issledovaniy vo VNIIMKe za 90 let. - Krasnodar, 2003. - S. 8-12.

24. D'yakov A.B. Metod selektsii sortov podsolnechnika akademika V.S. Pustovoyta i varianty ego opisaniya v raznykh publikatsiyakh // Maslichnye kul'tury. Nauch.-tekh. byul. VNIIMK. - Vyp. 2 (144145). - 2010. - S. 36-48.

25. Pustovoyt V.S. Metody raboty v oblasti vyvedeniya vysokomaslichnykh sortov podsolnechnika // Tr. Vses. nauch.-metod. soveshch. po masl. kul't. 16-21 iyunya 1946 g. - Krasnodar: Knigoizdatel'stvo, 1946. - S. 231-251.

26. Pustovoyt V.S. Rezul'taty i perspektivy selektsii i semenovodstva podsolnechnika // Tr. Vses. nauch.-proizv. soveshch. po masl. kul't. 25-29 iyunya 1951 g. - Krasnodar: Sovetskaya Kuban', 1952. - S. 224-242.

27. Pustovoyt V.S., D'yakov A.B. Urozhaynost' podsolnechnika i puti ee povysheniya $\mathrm{v}$ protsesse selektsii // Selektsiya i semenovodstvo. - 1971. - № 1. - S. 25-30.
28. Pustovoyt V.S., D'yakov A.B. O selektsii podsolnechnika na soderzhanie belka $\mathrm{v}$ semenakh // Vestnik s.-kh. nauki. - 1972. - № 7. - S. 11-15.

29. D'yakov A.B., Boyko Yu.G., Vasil'eva T.A. Vozmozhnosti povysheniya intensivnosti otborov iz perekrestnoopylyayushchikhsya populyatsiy // Maslichnye kul'tury. Nauch.-tekh. byul. VNIIMK. 2003. - Vyp. 2 (129). S. 3-24.

30. Anaschenko A.V. The initial material for sunflower heterosis breeding // Proc. of $6^{\text {th }}$ Intern. Sunfl. Conf. Bucharest, Romania, 22-24 July, 1974. - P. 391-393.

31. Seiler G., Jan C.C. Basic information // Genetics, genomics and breeding of sunflower / $\mathrm{Hu} \mathrm{J}$, Seiler G. (Eds). - USA, 2010. - P. 1-50.

32. Debaeke P., Casadebaig P., Flenet F., Langlade $N$. Sunflower crop and climate change in Europe: vulnerability, adaptation and mitigation potential // Proc. of $19^{\text {th }}$ Intern. Sunfl. Conf., Turkey, Edirne, 29 May - 2 June, 2016. - P. 71-87.

33. Encheva $V$. Changes in the pathogenic composition, attacking the oil sunflower in Bulgaria // Proc. of $19^{\text {th }}$ Intern. Sunfl. Conf., Turkey, Edirne, 29 May - 2 June, 2016. - P. 391-393.

34. Gurkan H., Bayractar N., Bulut H., Kocak N., Eskioglu O., Demircan M. The effect of climate factors on the yield of sunflower and sunflower yield predictions based on climate change projections: example of Marmara region // Proc. of $19^{\text {th }}$ Intern. Sunfl. Conf., Turkey. Edirne, 29 May - 2 June, 2016. - P. 919-929.

35. Vick B.A., Hu J. Future prospects // Genetic, genomics and breeding of sunflower / Hu J., Seiler G. (Eds). - USA, 2010. - P. 313-335.

36. Demir I. Determination of the yield and yield components performance of some sunflower (Helianthus annuus L.) under rainfed conditions // Proc. of $19^{\text {th }}$ Intern. Sunfl. Conf., Edirne, Turkey, 29 May -2 June, 2016. - P. 985-992.

37. Khan M., Kausar M., Rauf S., Hussain M. Evaluation of sunflower (Helianthus annuus L.) single cross hybrids under heat stress condition // Proc. of $19^{\text {th }}$ Intern. Sunfl. Conf., Turkey, Edirne. 29 May -2 June. 2016. - P. 118-128.

38. Tarik A.J., Gursham S.G. Sunflower cultivation in Iraq // Proc. of $6^{\text {th }}$ Intern. Sunfl. Conf., Romania, Bucharest, 22-24 July, 1974. - P. 83-84.

39. Downes R.W. Breeding sunflowers for mediterranean type climatic conditions // Proc. of $6^{\text {th }}$ Intern. Sunfl. Conf., Romania, Bucharest, 22-24 July, 1974. - P. 395-399.

40. Boujghagh M. Comportement de dix genotypes de tournesol en semis d' hiver dans trios sites pedoclimatiques marocains // Helia. - 1993. - V. 16. No 19. - P. 31-44.

41. Sinskaya E.N. Napravlenie i iskhodnyy material $\mathrm{v}$ selektsii maslichnykh kul'tur // Tr. nauch.metodich. soveshch. po masl. kul't. 16-21 iyunya 1946. - Krasnodar, 1946. - S. 89-111. 
42. Gimeno $V$. Variation in rate of germination at low temperature as a basic for selection in sunflowers // Proc. of $6^{\text {th }}$ Intern. Sunfl. Conf., Romania, Bucharest, 22-24 July. 1974. - P. 471-472.

43. Macchia M., Benvenuti M., Baldanzi M. Temperature requirements during germination in sunflower // Proc. of $11^{\text {th }}$ Intern. Sunfl. Conf., Argentina, Mar del Plata, March 10-13, 1985. - V.1. - P. 93-97.

44. Sin G., Hera C., Pintilie C. Improved cultural practices for sunflower hybrids // Proc. of $7^{\text {th }}$ Intern. Sunfl. Conf., USSR, Krasnodar 27 June - July 3, 1976. - V. 2. - P. 19-26.

45. Downes R.W. Factors affecting germination of sunflower under low temperature conditions // Proc. of $11^{\text {th }}$ Intern. Sunfl. Conf., Argentina, Mar del Plata, Match 10-13. 1985. - V.1. - P. 87-92.

46. Klyuka V.I., Araslanova N.M. Ispol'zovanie kamer iskusstvennogo klimata dlya otsenki selektsionnogo materiala podsolnechnika po rannevskhozhesti i skorospelosti // Sb. nauchnykh rabot: Ispol'zovanie fitotrona $\mathrm{v}$ selektsii maslichnykh kul'tur. - Krasnodar, 1984. - S. 41-44.

47. Dozet B. Sunflower breeding achievement and challenges // Proc. of Intern. Symp. on confection sunflower technology and production, Wuyuan, China, August 8-10, 2018. - P. 55.

48. Kaya Y., Beser N. Confectionery sunflower hybrid breeding studies in Turkey: current and future strategies // Proc. of Intern. Symp. on confection sunflower technology and production. Wuyuan, China, August 8-10, 2018. - P. 51-52.

49. Hladni N., Miklic V., Jocic S., Miladinovic D., Dimitrijevic A., Jockovic M., Cvejic S., Dedic B., Marjanovic A. Achievements and future prospects of NS confectionery breeding program // Proc. of Intern. Symp. on confection sunflower technology and production. Wuyuan, China, August 8-10, 2018. - P. 7778.

50. Aytac S., Arslanoglu S., Yigen C. Some morphological characteristics of confectionary sunflower genotypes obtained through selection breeding // Proc. of $19^{\text {th }}$ Intern. Sunfl. Conf. - Turkey. - Edirne. - May 29 - June 2. - 2016. - P. 1102-1105.

51. Byamukama E. Major sunflower diseases and their management in USA: A review // Proc. of Intern. symp. on confection sunflower technology and production, Wuyuan, China, August 8-10, 2018. - P. 27.

52. Masirevic S. Latest sunflower diseases research progress and management // Proc. of Intern. symp. on confection sunflower technology and production, Wuyuan, China, August 8-10, 2018. - P. 3334.

53. Sin G., Petcu G., Ionita S., Popa M. The influence of soil tillage and sowing technology on sunflower production // Proc. of $15^{\text {th }}$ Intern. Sunfl. Conf., France, Toulouse, June 12-15, 2000. - V.1. - P. 150155.
54. Baumer C.R., Gonzalez N., Devito C. Fertilization profunda del girasol en siemera directa en la region Pampeana Argentina // Proc. of $15^{\text {th }}$ Intern. Sunfl. Conf., France, Toulouse, June 12-15, 2000. V. 1. - P. 159-164.

55. Flenet F., Debacke P., Casadebaig P. Could a crop model be useful for improving sunflower crop management // Proc. of $17^{\text {th }}$ Intern. Sunfl. Conf., Spain, Cordoba, June 8-12, 2008. - V. 1. - P. 13-18.

56. Marshall M.W., Al-Khatib K. Gene flow, growth and competitiveness of imazethapyr-resistant common sunflower (Helianthus annuus L.) // Proc. of $22^{\text {th }}$ Sunflower research workshop, Fargo, USA. January $18-19,2000 .-$ P. 150-153.

57. Bonary E., Vannozzi G.P., Benvenuti A., Baldini M. Modern aspects of sunflower cultivation techniques // Proc. of $13^{\text {th }}$ Intern. Sunfl. Conf., Italy, Pisa, September 7-11, 1992. - P. 3-51.

58. Crnobarac J., Skoric D., Dusanic N., Marinkovic B. Effect of cultural practices on sunflower yields in a period of several years in FR Yugoslavia // Proc. of $15^{\text {th }}$ Intern. Sunfl. Conf., France, Toulouse, June 12-15. 2000. - V. 1. - P. 13-18.

59. Giriray K. Present status and prospects of sunflower cultivation in India // Helia. -1991. - V. 14. No 15. - P. 113-116.

60. Manivannan N., Muralidharan $V$., Ravindirakumar M. Association between parent and progeny performance and their relevance in heterosis breeding of sunflower // Proc. of $16^{\text {th }}$ Intern. Sunfl. Conf., USA, Fargo, August 29 - September 2, 2004. P. 581-584.

61. Sheoran R.K. Rerspective and challenges to develop high yielding resistant and oil quality sunflower hybrids in India // Proc. of $19^{\text {th }}$ Intern. Sunfl. Conf., Turkey, Edirne, May 29 - June 2, 2016. - P. 324-330.

62. Georgiev G., Encheva V., Nenova N., Encheva Y., Valkova D., Peevska P., Penchev E. Production potential of new sunflower hybrids developed at Dobrudzha agricultural institute - General Toshevo // Proc. of $19^{\text {th }}$ Intern. Sunfl. Conf., Turkey, Edirne, May 29 - June 2, 2016. - P. 441-453.

63. Hristova-Cherbadzhi M., Molle E. Evaluation of variation on sunflower single crosses. // Proc. of $19^{\text {th }}$ Intern. Sunfl. Conf., Turkey, Edirne, May 29 - June 2, 2016. - P. 583-592.

64. Jinga V., Paica A., Dudoiu R., Gradila M., Manole D., Giumba A. The behavior of some sunflower cultivars to the major pest agents in the southeastern area of Romania // Proc. of $19^{\text {th }}$ Intern. Sunfl. Conf., Turkey, Edirne, May 29 - June 2, 2016. - P. 809-815.

65. Zhang Y. Report of the development of the sunflower industry in Chine // Proc. of Intern. Symp. on confection sunflower: technology and production. China, Wuyuan, August 8-10, 2018. - P. 18-21. 
66. Semenci A., Kaya Y., Sahin I., Citak N. Determination of the performances and adoption levels of sunflower cultivars based on resistance to broomrape in farm conditions in Thrace region // Helia. - 2010. V. 33. - No 53. - P. 69-76.

67. Bochkovoy A.D., Peretyagin E.A., Khatnyanskiy V.I., Kamardin V.A., Krivoshlykov K.M. Podsolnechnik: osobennosti sortovoy politiki v zavisimosti ot pochvenno-klimaticheskikh, tekhnologicheskikh i sotsial'no-ekonomicheskikh usloviy (obzor) // Maslichnye kul'tury. Nauch.-tekh. byul. VNIIMK. - 2018. - Vyp. 2 (174). - S. 120-134.

68. Miklic V., Ovuka J., Balalic I., Hladni N., Cvejic S., Miladinov Z., Jocic S. Effect of biostimulators on seed quality, yield and oil content in sunflower // Proc. of $19^{\text {th }}$ Intern. Sunfl. Conf., Turkey, Edirne, 29 May - 2 June, 2016. - P. 1027-1036.

69. Milev G., Georgiev G., Peevska P. Effect of the plant density and foliar fertilization on the yield from new Bulgarian hybrids of sunflower (Helianthus annuus L.) // Proc. of $19^{\text {th }}$ Intern. Sunfl. Conf., Turkey, Edirne, 29 May - 2 June, 2016. - P. 1010-1018.

70. Castro C., Moreira A., Rodriques J. Sunflower response to water stress and boron application // Proc. of $15^{\text {th }}$ Intern. Sunfl. Conf., France, Toulouse, June 12-15, 2000. - V. 1. - P. 145-149.

71. Castro C., Brighenti A., Leite R., Oliveira F. Interaction of Boron supplied by soil with foliar sprays in sunflower // Proc. of $16^{\text {th }}$ Intern. Sunfl. Conf., USA, Fargo, August 29 - September 2, 2004. V. 1. - P. 343-346.

72. Alonso L.C. Sunflower in Spain: past and present trends in an international context // Proc. of $17^{\text {th }}$ Intern. Sunfl. Conf., Spain, Cordoba, June 8-12, 2008. P. 53-68.

73. Suzer S., Buyuk H. Residual effects of spraying imidazolinone-famili herbicides on clearfield sunflower production from the point of view of crop rotation // Helia. - 2010. - V. 33. - No 52. - P. 2536.

74. Vear F. Classic genetics and breeding // Genetics, genomics and breeding of sunflower / Hu J., Seiler G., Kole C. (Eds). - USA, 2010. - P. 51-79.

75. Marshall M.W., Al-Khatib K. Gene flow, growth and competitiveness of imazethapyr-resistant common sunflower (Helianthus annuus L.) // Proc. of $22^{\text {th }}$ sunflower research workshop, USA, Fargo, January 18-19, 2000. - P. 150-153.

76. Marshall M.W., Massing R.A., Al-Khatib K. Imazethapyr resistant gene flow in sunflower // Proc. of sunflower research workshop, USA, Fargo, January 17-18, 2001. - P. 120-125.

77. Hladni N. Present status and future prospects of global confectionery sunflower production // Proc. of $19^{\text {th }}$ Intern. Sunfl. Conf., Turkey, Edirne, 29 May 2 June, 2016. - P. 47-60.
78. Bater B. Effects of IMI herbicides on controlling Orobanche in sunflower fields // Proc. of Intern. Symp. on Confection sunflower technology and production. China, Wuyuan, August 8-10, 2018. - P. 3738.

79. Беккер $X$. Селекция растений. - М.: Товарищество научных изданий КМК, 2015. - 425 с.

80. Hristova-Cherbadzhi M. Evaluation of variation on sunflower single crosses // Proc. of $19^{\text {th }}$ Intern. Sunfl. Conf., Turkey, Edirne, 29 May - June 2, 2016. P. 583-592.

81. Encheva J., Georgiev G., Valkova D., Encheva $V$. Development of sunflower hybrids resistant to herbisides // Proc. of $19^{\text {th }}$ Intern. Sunfl. Conf., Turkey, Edirne, May 29 - June 2, 2016. - P. 465-473.

82. Semerci A., Kaya Y., Sahin I., Citak N. Evaluation of the changes in the cost factors of sunflower produced in Thrace on the basis of the provinces in the research field and the sizes of enterprise // Helia. 2011. - V. 34. - No 54. - P. 147-158.

83. Kaya S.A., Durak S. Economic analysis of sunflower production in Turkey // Helia. - 2007. - V. 30. - No 47. - P. 105-114.

84. Luxita R., Gabriel A.F., Pacureanu J.M., Sava $E$., Victorita $M$. The behavior of sunflower hybrids in different environmental conditions in Romania // Proc. of $19^{\text {th }}$ Intern. Sunfl. Conf., Turkey, Edirne, 29 May - 2 June, 2016. - P. 827.

85. Peevska P., Georgiev G. A new Bulgarian sunflower hybrid Dea. // Proc. of $19^{\text {th }}$ Intern. Sunfl. Conf., Turkey. Edirne. May 29 - June 2, 2016. - P. 475-483.

86. Fernandez-Martinez J.M., Perez-Vich B., Velasco L. Sunflower. Oil crops // Handbook of plant breeding. / Vollmann J., Rajcan J. (Eds) - Springer. London, New York, 2009. - P. 155-232.

87. Christov M. Contribution of interspecific and intergeneric hybridization in sunflower breeding // Proc. of Intern. Symp. on Confection sunflower technology and production, China, Wuyuan, August 8-10, 2018. - P. 61-62.

Получено: 09.11.2020 Принято: 13.11.2020

Received: 09.11.2020 Accepted: 13.11.2020 